\title{
The fauna of phlebotomines (Diptera, Psychodidae) in different phytogeographic regions of the state of Maranhão, Brazil
}

\author{
José Manuel Macário Rebêlo ${ }^{1,2}$, Roseno Viana da Rocha ${ }^{3}$, Jorge Luiz Pinto Moraes ${ }^{2}$, \\ Cláudio Roberto Marques da Silva ${ }^{4}$, Francisco Santos Leonardo ${ }^{3} \&$ Gildário Amorim Alves ${ }^{2}$
}

\begin{abstract}
${ }^{1}$ Departamento de Biologia, Universidade Federal do Maranhão, Avenida dos Portugueses s/n, Campus do Bacanga, 65085-580 São Luís-MA, Brazil.
${ }^{2}$ Laboratório de Entomologia e Vetores, Departamento de Patologia, Universidade Federal do Maranhão, Praça Madre Deus, 2, 65025-560 São Luís-MA, Brazil.macariorebelo@uol.com.br.

${ }^{3}$ Fundação Nacional de Saúde - Distrito Sanitário de Codó. Rua 1o de Maio, 1879a, Centro, 65400-000 Codó-MA, Brazil.

${ }^{4}$ Mestrado em Biodiversidade e Conservação, Universidade Federal do Maranhão, Avenida. dos Portugueses, s/n, 65085-580 Bacanga-MA, Brazil.
\end{abstract}

\begin{abstract}
The fauna of phlebotomines (Diptera, Psychodidae) in different phytogeographic regions of the state of Maranhão, Brazil. Phlebotomine specimens were captured in domiciliary and forest environments in 47 municipalities between 1982 and 2005 with the aid of CDC light traps. A total of 91 species were found, of which four belonged to genus Brumptomyia and 87 to genus Lutzomyia, distributed among the following subgenera: Evandromyia (6), Lutzomyia (5), Micropygomyia (2), Nyssomyia (9), Pintomyia (2), Pressatia (3), Psathyromyia (6), Psychodopygus (14), Sciopemyia (4), Trichophoromyia (2), Viannamyia (2); species groups: Aragaoi (2), Baityi (1), Dreisbachi (1), Migonei (12), Oswaldoi (8), Pilosa (1), Saulensis (2), Verrucarum (4) and ungrouped (1). Species diversity was greatest in areas where there was dense evergreen seasonal forest (52 species), ombrophilous forest (31) and meridional cerrados (23) and lowest in areas with mixed forest (forest with babassu palms, cerrado and caatinga). The greatest similarity index was observed for restinga and open evergreen seasonal forest $(\mathrm{J}=0.48)$. Dense evergreen seasonal forest had greatest similarity with ombrophilous forest $(\mathrm{J}=0.38)$. The phlebotomine fauna was species rich and unevenly distributed in Maranhão, reflecting the phytogeographical complexity of the state, which is a result of the great variety of ecosystems and climate zones.
\end{abstract}

KEYWORDS. Amazon; Babassu palm forests; Cerrado; Phlebotominae.

RESUMO. Fauna de flebotomíneos (Diptera, Psychodidae) em municípios de diferentes fitorregiões, no estado do Maranhão, Brasil. Espécimes de flebotomíneos foram capturados nos anos de 1982 a 2005, em ambientes domiciliares e florestais de 47 municípios, com uso de armadilhas luminosas CDC. Foram encontradas 91 espécies, sendo quatro pertencentes ao gênero Brumptomyia e 87 ao gênero Lutzomyia, distribuídas nos seguintes subgêneros: Evandromyia (6), Lutzomyia (5), Micropygomyia (2), Nyssomyia (9), Pintomyia (2), Pressatia (3), Psathyromyia (6), Psychodopygus (14), Sciopemyia (4), Trychophoromyia (2), Viannamyia (2); grupo de espécies: Aragaoi (2), Baityi (1), Dreisbachi (1), Migonei (12), Oswaldoi (8), Pilosa (1), Saulensis (2), Verrucarum (4) e não agrupada (1). A diversidade de espécies foi maior nas áreas de floresta estacional perenifólia densa (52 espécies), floresta ombrófila (31) e cerrados meridionais (23), sendo menor nas áreas de matas mistas (floresta com babaçu, cerrado e caatinga). O maior índice de similaridade foi observado entre a restinga e a floresta estacional perenifólia aberta $(\mathrm{J}=0,48)$. A floresta estacional perenifólia densa apresentou maior similaridade com a floresta ombrófila $(\mathrm{J}=0,38)$. A fauna de flebotomíneos mostrou-se rica e distribuída de maneira heterogênea no Maranhão, concordando com a complexidade fitogeográfica do Estado, que se manifesta na riqueza de ecossistemas e de zonas climáticas.

PALAVRAS-CHAVE. Amazônia; Cerrado; Cocais; Phlebotominae.

Phlebotomines are dipteran vectors of leishmaniasis and are found in all zoogeographic regions of the world. On the American continent, they are found from southernmost Canada to northern Argentina (Martins \& Morales-Farias 1972; Martins et al. 1978) but are present in greater variety in the Neotropical region, where approximately 480 species have already been catalogued (Aguiar \& Medeiros 2003).

Phlebotomines occurs in all Brazilian states with approximately 229 known species in the country (Aguiar \& Medeiros 2003). In the state of Maranhão, phlebotomines are relatively well known. Rebêlo et al. (1996) published a preliminary list of 40 species that had been found in the state up to that time. Since then, standardized fauna surveys have been carried out in various areas, including São Luís island (Rebelo et al. 1999a; Araújo et al. 2000; Barros et al.
2000; Carvalho et al. 2000; Marinho et al. 2008) and the municipalities of Codó (Rebêlo et al. 1999b), Buriticupu (Rebêlo et al. 2000a, b) and Santa Quitéria (Martin \& Rebêlo 2006). These studies provided new records and showed that many species normally found in sylvatic environments have invaded anthropic environments and adapted to the peridomicile, where they coexist with domestic animals and can enter dwellings, suck human blood and transmit leishmania (Dias et al. 2003; Oliveira-Pereira et al. 2006, 2008).

In the present study, the list published by Rebêlo et al. (1996) is updated and the distribution of phlebotomines in the various phytogeographical regions of the state of Maranhão is briefly discussed. 


\section{MATERIAL AND METHODS}

Study area. The state of Maranhão, which is in the west of Northeastern Brazil, between $01^{\circ} 01^{\prime}$ and $10^{\circ} 21^{\prime} \mathrm{S}$ and $41^{\circ}$ $48^{\prime}$ and $48^{\circ} 50^{\prime} \mathrm{W}$, covers an area of $328,630 \mathrm{~km}^{2}$, or $3.86 \%$ of the total area of Brazil. It has a coastline of $640 \mathrm{~km}$ and shares borders with the states of Piauí to the east $(1365 \mathrm{~km})$, Pará to the west $(798 \mathrm{~km})$ and Tocantins to the southwest $(1,060 \mathrm{~km})$. It has a number of different phytogeographic regions (Fig.1), which are classified as follows by the IBGE (Brazilian Institute of Geography and Statistics) (1984):

DESF - Dense evergreen seasonal forest is found in the northwest of the state, where there is a hot, humid equatorial climate with a mean annual temperature of $26^{\circ} \mathrm{C}$, mean relative humidity of $80 \%$ and annual rainfall of 1,800 to $2,200 \mathrm{~mm}^{3}$.

OESF - Open evergreen seasonal forest is also found in the northwest of the state but forms a mixed zone of OESF/B (open evergreen seasonal forest with babassu palms) in the central region and $\mathrm{OESF} / \mathrm{B} / \mathrm{C}$ (open evergreen seasonal forest with babassu palms and cerrado [savanna-like grasslands]) to the east. These mixed zones have a semi-humid climate, with annual rainfall between 1,400 and $1,800 \mathrm{~mm}^{3}$.

$\mathrm{OF}-$ Ombrophilous forest is primary forest in the interior of São Luís island, and is most common around the springs of the main watercourses. RE - Restinga (sandy coastal strips and their characteristic vegetation) is located behind the dunes along the northeastern coast of the state; and CC - Cerrado with fragments of caatinga (an area with xerophilous spiny trees and shrubs) is found in the Lower Parnaíba region, in the Northeast of the state.

MC - Meridional cerrado covers the eastern and southern regions of the state from the springs of the Grajaú and Mearin rivers to the upper reaches of the Balsas and Parnaíba rivers. It covers an area of 9,800 ha and has two different physiognomies (cerradão [forest savannah] and cerrado), the latter being the more common (Eiten 1994). The climate is more arid, with mean annual rainfall of approximately 1,000 to $1,200 \mathrm{~mm}^{3}$. RE occupies a large area where it meets the lençóis maranhenses (coastal dune fields) and is limited to the east by mixed zones of CC in the Lower Parnaíba region. $\mathrm{OF}$, which is considered a remnant of the Amazon forest, is found on São Luís island, where it helps to preserve a large green area and springs.

The study area itself consisted of 291 locations, including fragments of secondary vegetation and modified primary forest, in 47 municipalities in the phytogeographic regions referred to above. These locations were chosen because they contain foci for transmission of leishmaniasis.

Data collection. The phlebotomines were captured during the period 1982 to 2005 (from a minimum of one collection to a maximum of 12 collections over a period of one year, always between $6 \mathrm{pm}$ and $6 \mathrm{am}$ ) using CDC (Centers for Disease Control) light traps installed at a height of $1.5 \mathrm{~m}$ inside human dwellings, in shelters for domestic animals in the peridomicile and on trails inside forests. The specimens collected were killed in chambers containing ethyl acetate, placed in polyethylene flasks and sent to the laboratory, where they were identified taxonomically using the method described by Ryan (1986) and Young \& Duncan (1994).

Data analysis. To gain a better understanding of how the species were distributed, the municipalities were grouped according to the phytogeographic regions in which they are located. A group analysis was then carried out and a cladogram was obtained based on the Jaccard index, which takes into account the presence or absence of species.

\section{RESULTS}

A total of 91 phlebotomine species were found, of which four belonged to genus Brumptomyia and 87 to genus Lutzomyia, distributed among the following subgenera and groups: Evandromyia (6), Lutzomyia (5), Micropygomyia (2), Nyssomyia (9), Pintomyia (2), Pressatia (3), Psathyromyia (6), Psychodopygus (14), Sciopemyia (4), Trichophoromyia (2), Viannamyia (2); groups of species: Aragaoi (2), Baityi (1), Dreisbachi (1), Migonei (12), Oswaldoi (8), Pilosa (1), Saulensis (2), Verrucarum (4) and one that does not belong to any group (1).

Species list:

Genus Brumptomyia

1. B. avellari (Costa Lima, 1932)

2. B. brumpti (Larrousse, 1920)

3. B. pintoi (Costa Lima, 1932)

4. B. travassosi (Mangabeira, 1942)

Genus Lutzomyia

Subgenus Evandromyia

5. L. bourrouli (Barretto \& Coutinho, 1941)

6. L. brachyphalla (Mangabeira, 1941)

7. L. infraspinosa (Mangabeira, 1941)

8. L. monstruosa (Floch \& Abonnenc, 1944)

9. L. pinottii (Damasceno \& Arouck, 1956)

10. L. teratodes (Martins, Falcão \& Silva, 1964)

Subgenus Lutzomyia

11. L. carvalhoi (Damasceno, Causey \& Arouck, 1945)

12. L. dispar (Martins \& Silva, 1963)

13. L. gomezi (Nitzulescu, 1931)

14. L. longipalpis (Lutz \& Neiva, 1912)

15. L. spatotrichia (Martins, Falcão \& Silva, 1963)

Subgenus Micropygomyia

16. L. micropyga (Mangabeira, 1942)

17. L. oliveirai (Martins, Silva \& Falcão, 1970)

Subgenus Nyssomyia

18. L. anduzei (Rozeboom, 1942)

19. L. antunesi (Coutinho, 1939)

20. L. flaviscutellata (Mangabeira, 1942)

21. L. inornata (Martins, Falcão \& Silva, 1965)

22. L. intermedia (Lutz \& Neiva, 1912)

23. L. olmeca nociva (Young \& Arias, 1982)

24. L. richardwardi (Ready \& Fraiha, 1981)

25. L. umbratilis (Ward \& Fraiha, 1977)

26. L. whitmani (Antunes \& Coutinho, 1939)

Subgenus Pintomyia

27. L. christenseni (Young \& Duncan, 1994) 


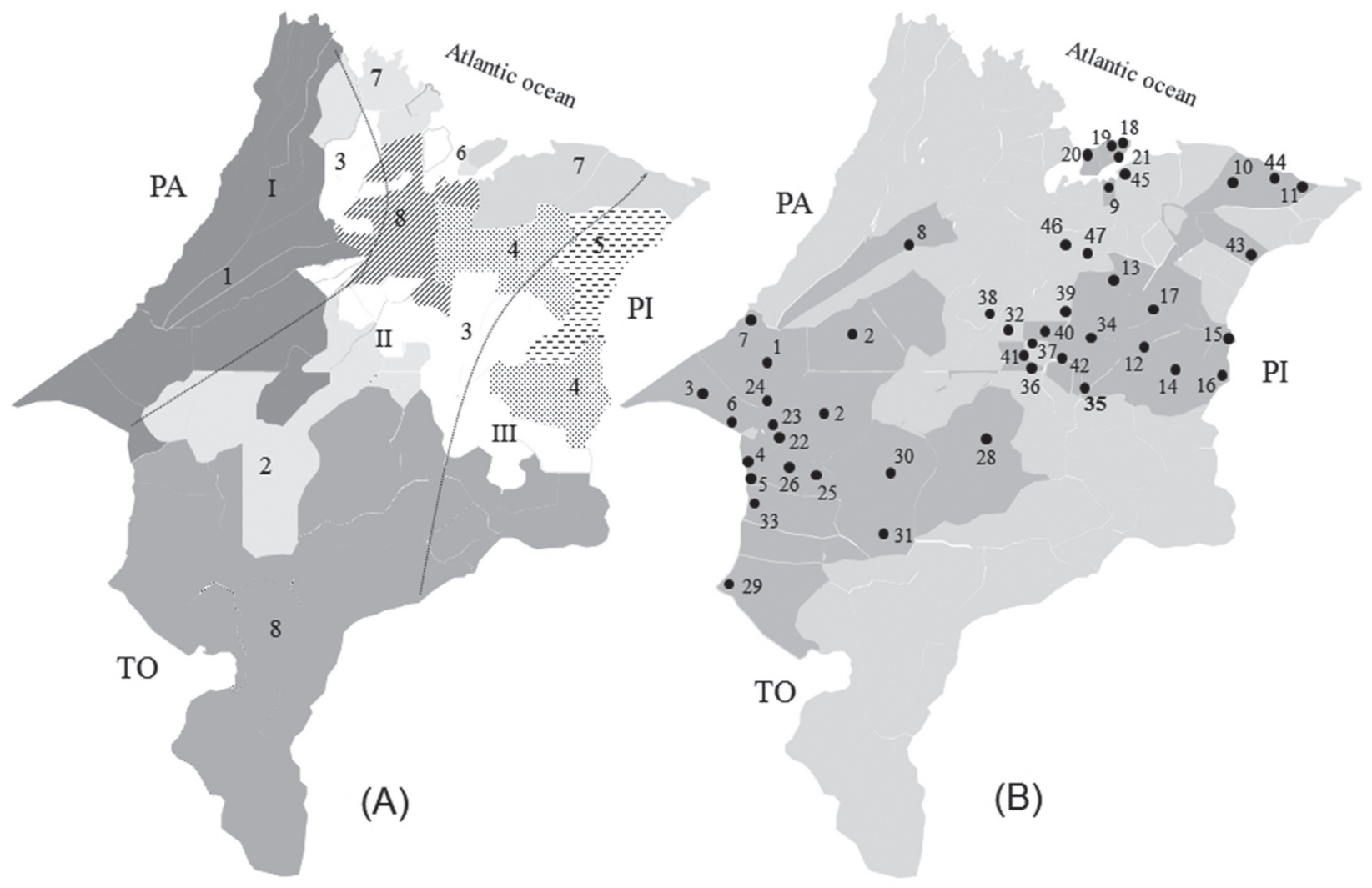

Fig. 1. Map of the Maranhão State. A. Phytoregions. . 1) Dense Evergreen Seasonal Forest; 2) Open Evergreen Seasonal Forest; 3) Open Evergreen Seasonal Forest with Babassu Palms; 4) Open Evergreen Seasonal Forest with Babassu Palms and Cerrado Fragments; 5) Cerrado with Caatinga Fragments; 6) Ombrophilous Forest; 7) Restinga; 8) Meridional Cerrado. I) Hot and humid climate; II) Semi-humid climate and III) Semi-arid climate. B. Towns with occurrence of sand flies: 1) Açailândia; 2) Buriticupu; 3) Cidelândia; 4) Davinópolis; 5) Governador Edson Lobão; 6) Imperatriz; 7) Itinga; 8) Zé Doca; 9) Axixá; 10) Barreirinhas; 11) Tutóia; 12) Codó; 13) Coroatá; 14) Caxias; 15) Coelho Neto; 16) Timon; 17) Timbiras; 18) Paço do Lumiar; 19) Raposa; 20) São Luís; 21) São José de Ribamar; 22) Amarante; 23) Buritirana; 24) João Lisboa; 25) Lageado Novo; 26) Montes Alto; 27) Senador La Roque; 28) Barra do Corda; 29) Carolina; 30) Formosa Serra Negra; 31) Grajaú; 32) Lago dos Rodrigues; 33) Porto Franco; 34) Capinzal do Norte; 35) Dom Pedro; 36) Esperantinópolis; 37) Igarapá Grande; 38) Lago da Pedra; 39) Lima Campos; 40) Pedreiras; 41) Poção de Pedra; 42) Santo Antonio dos Lopes; 43) Santa Quitéria, 44) Paulino Neves, 45) Icatu, 46) Itapecuru and 47) Vargem Grande.

28. L. damascenoi (Mangabeira, 1941)

Subgenus Pressatia

29. L. choti (Floch \& Abonnenc, 1941)

30. L. triacantha (Mangabeira, 1942)

31.L. trispinosa (Mangabeira, 1942)

Subgenus Psathyromyia

32. L. dendrophyla (Mangabeira, 1942)

33. L. abonnenci (Floch \& Chassignet, 1947)

34. L. lutziana (Costa Lima, 1932)

35. L. punctigeniculata (Floch \& Abonnenc, 1944)

36. L. scaffi (Damasceno \& Arouck, 1956)

37. L. shannoni (Dyar, 1929)

Subgenus Psychodopygus

38. L. amazonensis (Root, 1934)

39. L. arthuri (Fonseca, 1936)

40. L. ayrozai (Barretto \& Coutinho, 1940)

41. L. carrerai carrerai (Barretto, 1946)

42. L. claustrei (Abonnenc, Léger \& Fauran, 1979)

43. L. complexa (Mangabeira, 1941)

44. L. corossoniensis (Le Pont \& Pajot, 1978)

45. L. davisi (Root, 1934)

46. L. geniculata (Mangabeira, 1941)
47. L. hirsuta hirsuta (Mangabeira, 1942)

48. L. lloydi (Antunes, 1937)

49. L. paraensis (Costa Lima, 1941)

50. L. squamiventris (Lutz \& Neiva, 1912)

51. L. wellcomei (Fraiha, Shaw \& Lainson, 1971)

Subgenus Sciopemyia

52. L. fluviatilis (Floch \& Abonnenc, 1944)

53. L. microps (Mangabeira, 1942a)

54. L. servulolimai (Damasceno \& Causey, 1945)

55. L. sordellii (Shannon \& Del Ponte, 1927)

Subgenus Trichophoromyia

56. L. ubiquitalis (Mangabeira, 1942a)

57. L. viannamartinsi (Sherlock \& Guitton, 1970)

Subgenus Viannamyia

58. L. furcata (Mangabeira, 1941)

59. L. tuberculata (Mangabeira, 1941)

Group Aragaoi

60. L. aragaoi (Costa Lima, 1932)

61. L. brasiliensis (Costa Lima, 1932)

Group Baityi

62. L. baityi (Damasceno, Causey \& Arouck, 1945) 


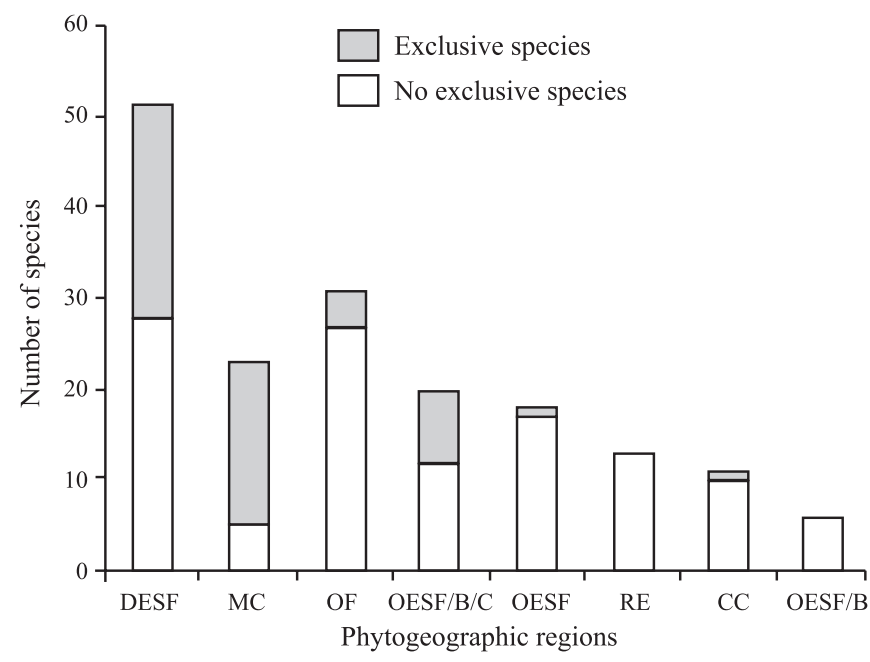

Fig. 2. Number of species of phlebotomines captured in the state of Maranhão from 1982 to 2005 by phytogeographic region. DESF = Dense Evergreen Seasonal Forest; OESF - Open Evergreen Seasonal Forest; OESF/B - Open Evergreen Seasonal Forest with Babassu Palms; CC-Cerrado with Caatinga Fragments; OESF/B/C - Open Evergreen Seasonal Forest with Babassu Palms and Cerrado Fragments; RE-Restinga; OF - Ombrophilous Forest; $\mathrm{MC}=$ Meridional Cerrado

\section{Group Dreisbachi}

63. L. hermanlenti (Martins, Silva \& Falcão, 1970)

Group Migonei

64. L. bacula (Martins, Falcão \& Silva, 1965)

65. L. carmelinoi (Ryan, Fraiha, Lainson \& Shaw, 1986)

66. L. cortelezzii (Brèthes, 1923)

67. L. corumbaensis (Galati, Nunes, Oshiro \& Rego, 1989)

68. L. edwardsi (Mangabeira, 1941a)

69. L. evandroi (Costa Lima \& Antunes, 1936)

70. L. lenti (Mangabeira, Mangabeira, 1938)

71. L. migonei (França, 1920)

72. L. pacae (Floch \& Abonnenc, 1943)

73. L. sallesi (Galvão \& Coutinho, 1939)

74. L. termitophila (Martins, Falcão \& Silva, 1964)

75. L. walkeri (Newstead, 1914)

Group Oswaldoi

76. L. longipennis (Barretto, 1946)

77. L. goiana (Martins, Falcão \& Silva, 1962)

78. L. oswaldoi (Mangabeira, 1942)

79. L. peresi (Mangabeira, 1942)

80. L. pusilla (Dias, Martins, Falcão \& Silva, 1986)

81. L. quinquefer (Dyar, 1929)

82. L. rorotaensis (Floch \& Abonnenc, 1944)

83. L. trinidadensis (Newstead, 1922)

Group Pilosa

84. L. pilosa (Damasceno \& Causey, 1944)

Group Saulensis

85. L. saulensis (Floch \& Abonnenc, 1944)

86. L. wilsoni (Damasceno \& Causey, 1945)

Group Verrucarum

87. L. odax (Fairchild \& Hertig, 1961b)

88. L. orestes (Fairchild \& Trapido, 1950)

89. L. nevesi (Damasceno \& Arouck, 1956)

90. L. serrana (Damasceno \& Arouck, 1949)

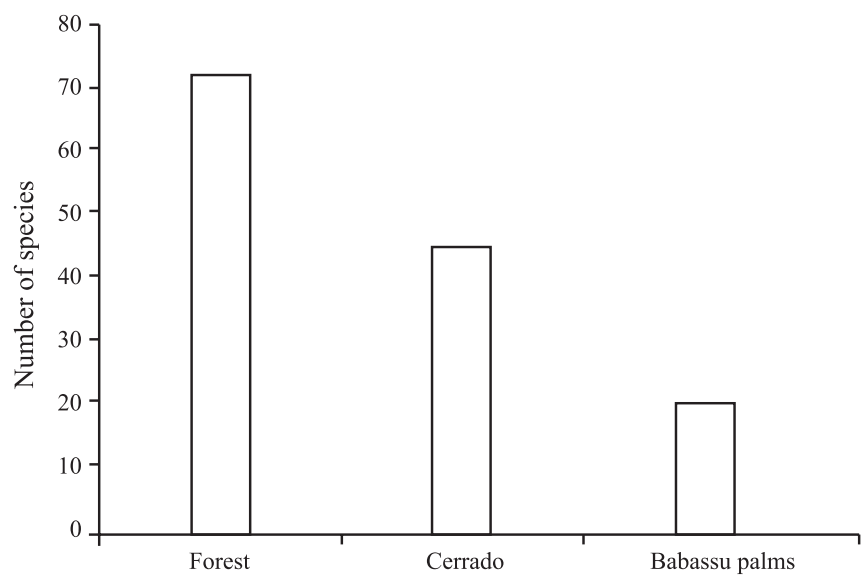

Fig. 3. Number of phlebotomines species found in forest, cerrado and babassu palms area, in the state of Maranhão.

No group

91.L. samueli (Deane, 1955)

Table I shows the distribution of the species in the different phytogeographic regions of the state of Maranhão. Species richness was greatest in OESF (52 species), followed by OF (31), MC (23), OESF/B/C (20), OESF (18), RE (13), CC (11) and $\mathrm{OESF} / \mathrm{B}(6)$.

Fifty-six species, or $61.5 \%$ of the phlebotomine fauna, were present in only one type of phytogeographic region (Fig. 2). In absolute numbers, OESF accounted for the largest number of exclusive species (24), followed by $\mathrm{MC}$ (18), OESF/B/C (8), OF (4), OESF (1) and CC (1). However, when expressed as a percentage of the number of species in a particular phytogeographic region, the number of exclusive species was highest in MC (78.3\%), followed by OESF (46.2\%), OESF/B/C (40\%) and OF (12.9\%).

When the species distribution is analyzed by phytogeographic region, it can be seen that those areas with forest cover (OESF, OESF, OESF/B, OESF/B/C and OF) accounted for 72 species (Fig. 3), or $79.1 \%$ of the phlebotomine fauna in Maranhão. The areas with cerrado (MC, $\mathrm{CC}$ and $\mathrm{OESF} / \mathrm{B} / \mathrm{C}$ ) accounted for 45 species (49.5\%), and those where there were coconut palm forests $(\mathrm{OESF} / \mathrm{B} / \mathrm{C}$ and $\mathrm{OESF} / \mathrm{B})$ accounted for a total of 21 species $(23.1 \%)$ (Fig. 3).

Analysis of Figure 4 shows that the phlebotomine communities with the highest similarity index were those in RE and OESF (0.48), RE and OESF/B (0.46), CC and OESF/B (0.42), RE and CC (0.41) and OESF and OF (0.38). The fauna in $\mathrm{OESF} / \mathrm{B} / \mathrm{C}$ showed some similarity with that in FEPA (0.32), CC (0.30), RE (0.28) and OESF/B (0.25).

The most widely distributed species were L. longipalpis and L. whitmani, which were found in all eight phytogeographic regions (Tab. I). Notable among the other species were $L$. evandroi (found in seven regions), L. lenti, L. sordellii and $L$. termitophila (6), L. wellcomei (5), and B. avellari, L. goiana, L. longipennis and L. migonei (4); the remaining species were found in one to three regions. 
Table I. Distribution of phlebotomine species in the state of Maranhão by phytogeographic region. DESF $=$ Dense Evergreen Seasonal Forest; OESF - Open Evergreen Seasonal Forest; OESF/B - Open Evergreen Seasonal Forest with Babassu Palms; CC-Cerrado with Caatinga Fragments; OESF/ B/C - Open Evergreen Seasonal Forest with Babassu Palms and Cerrado Fragments; RE-Restinga; OF - Ombrophilous Forest; $\mathrm{MC}=$ Meridional Cerrado.

\begin{tabular}{lc}
\hline & \multicolumn{2}{c}{ Phytogeographic region } \\
\cline { 2 - 2 } Phlebotomine & DESF OESF OESF CC OESF RE OF MC Total \\
species & \multicolumn{1}{c}{ /B $/ B C$}
\end{tabular}

\begin{tabular}{lllcccc} 
species & \multicolumn{5}{c}{ /B } & /BC \\
\hline Brumptomyia & $\mathrm{X}$ & $\mathrm{X}$ & & $\mathrm{X}$ & $\mathrm{X}$ & 4
\end{tabular}

avellari

B. brumpti

B. pintoi

B. travassosi $\mathrm{X}$

Lutzomyia $\quad \mathrm{X}$

abonnenci

L. amazonensis

L. anduzei

L. antunesi

L. aragaoi

L. arthuri

L. ayrozai

L. bacula

L. baityi

L. bourrouli

L. brachyphalla

L. brasiliensis

L. carmelinoi

L. carrerai

L. carvalhoi

L. choti

L. christenseni

L. claustrei

L. complexa

L. corossoniensis

L. cortelezzii

L. corumbaensis

L. damascenoi

L. davisi

L. dendrophyla

L.dispar

L. edwardsi

L. evandroi

L. flaviscutellata

L. fluviatilis

L. furcata

L. geniculata

L. goiana

L. gomezi

L. hermalenti

L. hirsute

L. infraspinosa

L. inornata

L. intermedia

L. lenti

L. lloydi

L. longipalpis

L. longipennis

L. lutziana

L. microps

L. micropyga

L. migonei

L. monstruosa

X

$\mathrm{X}$

$\mathrm{X}$

$\mathrm{X}$

$\mathrm{X}$

$\mathrm{X}$

$\mathrm{X}$

X

$\mathrm{x}$

$\mathrm{X} \quad \mathrm{X}$

$\mathrm{X}$

X

X

X

$\mathrm{X}$

$\mathrm{X}$

$\mathrm{X}$

X

$\mathrm{X}$

$$
\mathrm{x}
$$$$
\text { X X }
$$$$
\begin{array}{rl} 
& \mathrm{X} \\
\mathrm{X} & \mathrm{X}
\end{array}
$$$$
\text { X X }
$$

$\begin{array}{ll} & 1 \\ X & 1\end{array}$

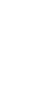

$\begin{array}{ll}X & X \\ X & X\end{array}$

X

X X

X

X

$\mathrm{X}$

X

$$
\text { X }
$$

X

$$
\begin{array}{llll} 
& & X & \\
X & X & X & X \\
X & & & \\
X & X & X & X \\
X & X & &
\end{array}
$$$$
\begin{array}{r}
\mathrm{X} \\
\mathrm{X}
\end{array}
$$$$
\mathrm{X}
$$$$
\text { X } 1
$$$$
\text { X } 1
$$$$
\begin{array}{ll}
X & X \\
X & X
\end{array}
$$$$
3
$$$$
x
$$$$
\begin{aligned}
& \mathrm{X} \\
& \mathrm{X}
\end{aligned}
$$$$
\begin{array}{lllll}
\mathrm{X} & \mathrm{X} & \mathrm{X} & \mathrm{X} & 8 \\
\mathrm{X} & & \mathrm{X} & & 4
\end{array}
$$$$
\text { X }
$$$$
\text { X } 1
$$

X

$\begin{array}{ll}\mathrm{X} & 1 \\ \mathrm{X} & 4 \\ & 1\end{array}$

.

Table I. Cont.

Phytogeographic region

Phlebotomine

DESF OESF OESF CC OESF RE OF MC Total

L. scaffi

L. teratodes

L. termitophila

L. tuberculata species

L. nevesi

L. odax

L. oliveirai

L. olmeca nociva

L. orestes

L. oswaldoi

L. pacae

L. paraensis

L. peresi

L. pilosa

L. pinotti

L. punctigeniculata $\mathrm{X}$

L. pusilla

L. quinquefer

L. richardwardi

L. rorotaensis

L. salesi

L. samueli

L. saulensis

L. serrana

L. shannoni

L. servulolimai

L. sordellii

L. spatotrichia

L. squamiventris

L. triacantha

L. trinidadensis

L. trispinosa

L. ubiquitalis

L. umbratilis

L. vianamartinisi

L. walkeri

L. wellcomei

L. whitmani

L. wilsoni

Total

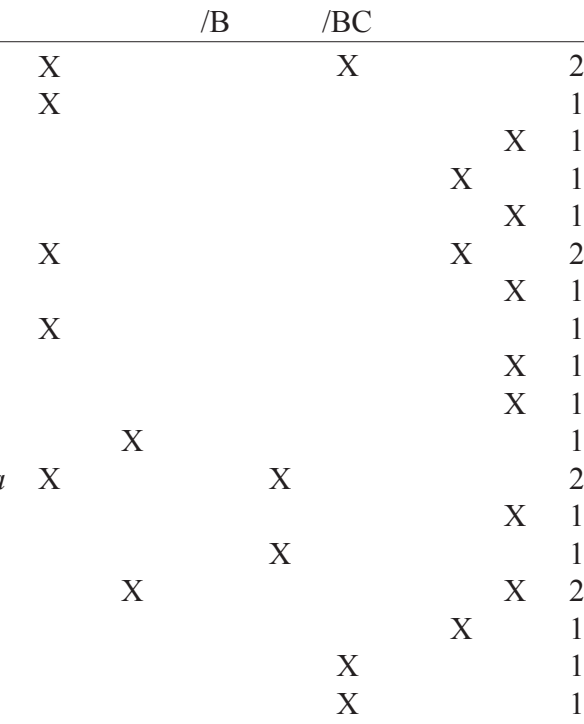

$\begin{array}{ll}\mathrm{X} & \\ \mathrm{X} & \\ \mathrm{X} & \\ \mathrm{X} & \\ \mathrm{X} & \\ \mathrm{X} & \mathrm{X} \\ \mathrm{X} & \end{array}$

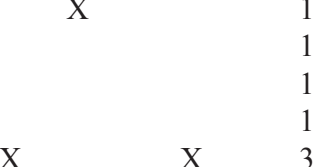$$
\begin{array}{llllll}
X & X & X & X & 6
\end{array}
$$$$
\begin{array}{llllllll} 
& & & \text { X } & & & & 1 \\
& & & \text { X } & & & & 1 \\
\text { X } & \text { X } & \text { X } & \text { X } & \text { X } & \text { X } & & 6 \\
\text { X } & & & & & \text { X } & & 2 \\
\text { X } & \text { X } & & \text { X } & & \text { X } & & 4 \\
\text { X } & & & & & \text { X } & & 2 \\
& & & & & & \text { X } & 1 \\
\text { X } & & & & & & & 1 \\
\text { X } & & & & & \text { X } & & 2
\end{array}
$$$$
\begin{array}{llllll}
X & & & 1 \\
X & & & & 1
\end{array}
$$$$
\begin{array}{lllllllll} 
& \mathrm{X} & \mathrm{X} & \mathrm{X} & & \mathrm{X} & \mathrm{X} & & 5 \\
\mathrm{X} & \mathrm{X} & \mathrm{X} & \mathrm{X} & \mathrm{X} & \mathrm{X} & \mathrm{X} & \mathrm{X} & 8
\end{array}
$$$$
\begin{array}{lllllllll}
52 & 18 & 6 & 11 & 20 & 13 & 31 & 23
\end{array}
$$

\section{DISCUSSION}

The phlebotomine fauna in the state of Maranhão is very species rich and is to date only exceeded in number of species by that in the states of Pará (117 species) and Amazonas (110). This result supports the hypothesis that phlebotomines are indeed more diversified in the Amazon basin, where at least 166 species have been found to date (Aguiar \& Medeiros 2003). Nevertheless, the variety of phlebotomine species found in Maranhão, encompassing a large number of subgenera and groups, reflects the climatic and phytogeographic complexity of the state, which is a consequence of its location between three Brazilian biomes: the Amazon Forest, Cerrado and Caatinga. As a result, the fauna in Maranhão consists of elements of fauna from the Amazon and Northeastern and Midwestern Brazil. 


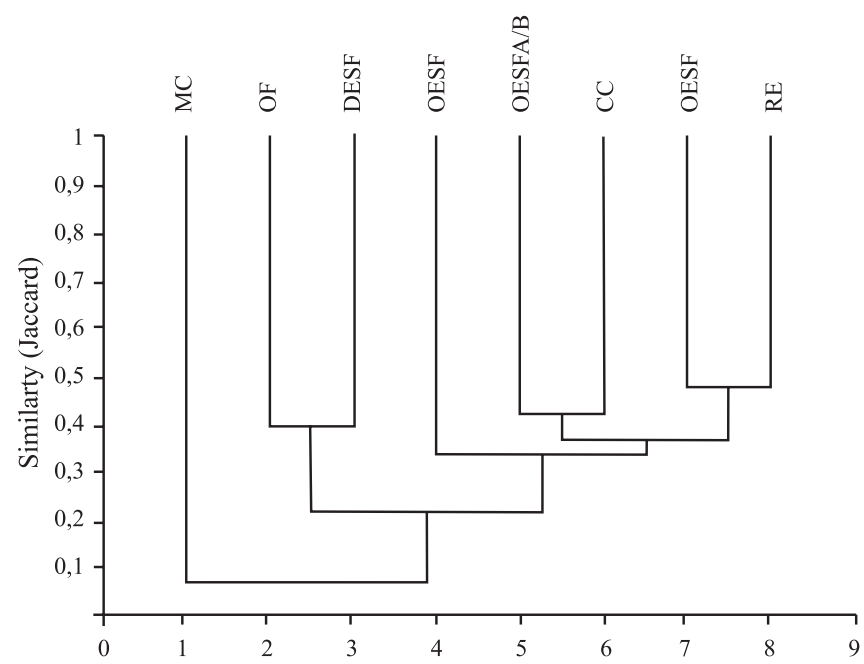

Fig. 4. Cladogram based on the Jaccard index, showed the similarity in the species composition of phlebotomines between vegetal formation of the state of Maranhão. DESF = Dense Evergreen Seasonal Forest; OESF - Open Evergreen Seasonal Forest; OESF/B - Open Evergreen Seasonal Forest with Babassu Palms; CC-Cerrado with Caatinga Fragments; RE-Restinga; OF Ombrophilous Forest; $\mathrm{MC}=$ Meridional Cerrado

Phytogeography is an important factor in explaining the diversity of phlebotomines in the state of Maranhão. The greater species richness observed in the municipalities in areas with dense evergreen seasonal forest can be explained by the essentially Amazonian characteristics of the vegetation, namely, heavy rainfall and high temperatures and humidity. Approximately $43 \%$ of the species found in this phytogeographic region do not go beyond the Pindaré river. They are therefore not found outside the region where the climate is hot and humid and are thus absent in the other phytogeographic regions in central-eastern Maranhão, where the climate is semi-humid and semi-arid. Surveys of euglossine bee fauna showed a similar pattern (Rebêlo \& Silva 1999; Silva \& Rebêlo 1999). The fact that the second greatest species richness was observed in areas where there is ombrophilous forest was expected, given the similarities between this type of vegetation and dense evergreen seasonal forest, both in terms of their structure and climate.

In contrast, areas with open forest and mixed vegetation have a semi-humid climate in a transition zone where the climate is changing to a semi-arid one, so that the number of species adapted to the hot and humid Amazon climate that are found is limited. However, approximately $57 \%$ of the species found in the Amazon regions are also found in an area that extends beyond these regions through areas of open evergreen seasonal forest into areas of mixed vegetation with, therefore, a more xeric climate. Thus, the overlap between open evergreen seasonal forest and coconut palm forests and cerrado, and in turn the overlap of the latter with caatinga (IBGE 1984), forms a mosaic of vegetation that results in a mixture of species from the Amazon and Northeast that is only found in these areas.

The opposite is observed in the meridional cerrado, which, because it is a homogeneous phytogeographic region covering the whole central-southern region of Maranhão, contains phlebotomine fauna that is particular to the region. A good idea of the extent to which the fauna is particular to this area can be had from the fact that $87.5 \%$ of the fauna in the meridional cerrado has not yet been detected outside this region, even in the areas of mixed vegetation in the north, where the cerrado is mixed with open forest and caatinga and phlebotomines have been studied in greater depth (Rebêlo et al. 1999b; Martin \& Rebêlo 2006). Indeed, these species are more common in areas to the south of Maranhão, including the neighboring state of Tocantins (Andrade Filho et al. 2001b), as well as Goiás, Distrito Federal (Carvalho et al. 1989), Mato Grosso (Azevedo et al. 2002, Missawa \& Maciel 2007) and Mato Grosso do Sul (Galati et al. 2006), all of which are in the cerrado. As the areas of meridional cerrado are less well studied than the forest areas, particularly in the very south of the state, a greater effort to capture phlebotomines may result in an increase in the number of known species in this phytogeographic region.

Analyzing the composition and distribution of phlebotomine species from another perspective, it can be seen that the fauna in Maranhão has a greater degree of similarity to that in Amazonian states, as $80.2 \%$ of the species in Maranhão (73 species) are also found in the neighboring state of Pará (see Ryan 1986; Rebêlo \& Oliveira-Pereira 2001; Aguiar \& Medeiros 2003). A smaller percentage (42.9\%) of species in Maranhão are also found in other states in Northeastern Brazil. Of these states, Bahia has the fauna with the greatest similarity to that in Maranhão - 30 (33\%) species are found in both states (see Aguiar \& Medeiros 2003) - possibly because it is one of the states in the region where more studies of phlebotomine fauna are carried out. Nonetheless, twelve species in Maranhão not yet found in Bahia can be found in the states of Piauí, Ceará and Pernambuco (see Andrade Filho et al. 2001a; Aguiar \& Medeiros 2003; Silva \& Vasconcelos 2005).

The study has also shown that the number of currently known phlebotomine species in Maranhão has increased by 56\% since the last list published by Rebêlo et al. (1996).

\section{REFERENCES}

Aguiar, G. M. \& W. M. Medeiros. 2003. Distribuição e habitats, p. 207-255. In: E.F. Rangel \& R. Lainson (Eds.). Flebotomíneos do Brasil. Rio de Janeiro, Fiocruz, 368 p.

Andrade Filho, J. D.; A. C. Lima da Silva \& A. L. Falcão. 2001a. Phlebotomine sand flies in the State of Piaui, Brazil (Diptera: Psychodidae: Phlebotominae). Memórias do Instituto Oswaldo Cruz 96: $1085-1087$.

Andrade Filho, J. D.; M. B. Valente; W. A. Andrade; R. P Brazil \& A. L Falcão. 2001b. Flebotomíneos do Estado de Tocantins, Brasil (Diptera: Psychodidae). Revista da Sociedade Brasileira de Medicina Tropical 34: 323-329.

Araújo, J. C.; J. M. M. Rebelo; M. L. Carvalho \& V. L. L. Barros. 2000. Composição dos flebotomíneos (Diptera, Psychodidae) do município da Raposa-MA, Brasil. Área endêmica de leishmanioses. Entomologia y Vectores 7: 33-47.

Azevedo, A.; N. A. Souza; C. R. V. Meneses; W. A. Costa; S. M. Costa; J. B. Lima \& E. F. Rangel. 2002. Ecology of sand flies (Diptera: Psychodidae: Phlebotominae) in north of the State of Mato Grosso, Brazil. Memórias do Instituto Oswaldo Cruz 97: 459-464. 
Barros, V. L.; J. M. M. Rebelo \& F. S. Silva. 2000. Flebotomíneos (Diptera, Psychodidae) de capoeira do município do Paço do Lumiar, Estado do Maranhão, Brasil. Área endêmica de leishmanioses. Caderno de Saúde Pública 16: 265-270.

Carvalho, M. E. S. D.; E. S. Lustosa \& H. A. M. Naves. 1989. Contribuição ao conhecimento da fauna flebotomínica do Estado de Goiás e Distrito Federal. II - 1986-1987. Revista de Patologia Tropical 18: 7-14.

Carvalho, M. L.; J. M. M. Rebelo \& J. C. Araújo. 2000. Aspectos ecológicos dos flebotomíneos (Diptera, Psychodidae) do município de São José de Ribamar, MA, Brasil. Área endêmica de leishmanioses. Entomologia y Vectores 7: 19-32.

Dias, F. O. P.; E. S. Lorosa \& J. M. M. Rebêlo. 2003. Fonte alimentar sanguínea e a peridomiciliação de L. longipalpis (Lutz \& Neiva, 1912) (Psychodidae, Phlebotominae). Caderno de Saúde Pública 19: 13731380.

Eiten, G. 1994. Duas travessias na vegetação do Maranhão. Brasília, Editora Sucesso, $76 \mathrm{p}$.

Galati, E. A. B.; V. L. B. Nunes; P. C. Boggiani; M. E. C. Dorval; G. Cristaldo; H. C. Rocha; E. T. Oshiro \& G. A. Damasceno-Júnior. 2006. Phlebotomines (Diptera: Psychodidae) in forested areas of the Serra da Bodoquena, state of Mato Grosso do Sul, Brazil. Memórias do Instituto Oswaldo Cruz 101: 175-193.

IBGE - Instituto Brasileiro de Geografia e Estatística. 1984. Atlas do Maranhão. Rio de Janeiro, $104 \mathrm{p}$.

Marinho, R. M. R. S. Fonteles; G. C. Vasconcelos; P. C. B. Azevêdo; J. L. P. Moraes; J. M. M. Rebêlo. 2008. Flebotomíneos (Diptera, Psychodidae) em reservas florestais da área metropolitana de São Luís, Maranhão, Brasil. Revista Brasileira de Entomologia 52: 112-116.

Martin, A. M. C. \& J. M. M. Rebêlo. 2006. Dinâmica espaço-temporal de flebotomíneos (Diptera, Psychodidae) do município de Santa Quitéria, área de cerrado do Estado do Maranhão, Brasil. Iheringia 96: 273-384.

Martins, A. V. \& E. M. Morales-Farias. 1972. Sobre a distribuição geográfica dos flebotomíneos americanos (Diptera, Psychodidae, Phlebotominae). Revista Brasileira de Biologia 32: 361-371.

Martins, A. V.; P. Williams \& A. L. Falcão. 1978. American Sand Flies. Rio de Janeiro, Academia Brasileira de Ciência, 195 p.

Missawa, N. A.\& G. B. M. L. Maciel. 2007. List of species in the genus Lutzomyia França, 1924 (Psychodidae; Phlebotominae) from the state of Mato Grosso. Revista da Sociedade Brasileira de Medicina Tropical 40: $11-14$.

Oliveira-Pereira, Y. N. O.; J. M. M. Rebêlo; J. L. P. Moraes \& S. R. F. Pereira. 2006. Diagnóstico molecular da taxa de infecção natural de flebotomíneos (Psychodidae, Lutzomyia) por Leishmania sp. Na
Amazônia maranhense. Revista da Sociedade Brasileira de Medicina Tropical 39: $540-543$.

Oliveira-Pereira, Y. N. O.; J. L. P. Moraes; E. S.Lorosa \& J. M. M. Rebelo. 2008. Preferência alimentar sanguínea de flebotomíneos da Amazônia do Maranhão, Brasil. Cadernos de Saúde Pública 24: 2183-2186.

Rebêlo, J. M. M \& Y. N. Oliveira- Pereira. 2001. Flebotomíneos (Diptera, Psychodidae) de matas de terra firme e de várzea, do município de Paragominas, Estado do Pará, Brasil. Acta Amazônica 31: 145-154.

Rebêlo, J. M. M. \& F. S. Silva. 1999. Distribuição das abelhas Euglossini (Hymenoptera: Apidae) no Estado do Maranhão, Brasil. Anais da Sociedade Entomológica do Brasil 28: 389-401.

Rebêlo, J. M. M.; W. A. Mendes; J. M. L. Costa \& N. Cavaleiro. 1996. Lista preliminar das espécies do gênero Lutzomyia Franá, 1924 (Phlebotominae, Psychodidae) do Estado do Maranhão-Brasil. Caderno Saúde Pública 12: 37-45.

Rebêlo, J. M. M.; J. C. Araújo; M. L. Carvalho; F. S. Silva \& S. T. Oliveira 1999a. Flebótomos (Diptera, Phlebotominae) da ilha de São Luís, zona do Golfão Maranhense, Brasil. Revista da Sociedade Brasileira de Medicina Tropical 32: 247-253.

Rebêlo, J. M. M.; F. S. Leonardo; J. M. L. Costa; Y. N. O. Pereira \& F. S. Silva. 1999b. Flebotomíneos (Diptera, Psychodidae) de área endêmica de leishmaniose na região dos cerrados, Estado do Maranhão, Brasil. Caderno Saúde Pública 15: 623-630.

Rebêlo, J. M. M.; S. T. Oliveira \& F. S. Silva. 2000a. Flebotomíneos (Diptera, Psychodidae) de Lagoas, município de Buriticupu, Amazônia maranhense. I - Riqueza e abundância relativa das espécies em área de colonização recente. Revista da Sociedade Brasileira de Medicina Tropical 33: 11-19.

Rebêlo, J. M. M.; S. T. Oliveira \& F. S. Silva. 2000b. Flebotomíneos da Amazônia maranhense. IV - Riqueza e abundância relativa das espécies em área de colonização antiga. Entomologia y Vectores 7: 61-72.

Ryan, L. 1986. Flebótomos do Estado do Pará, Brasil. Documento Técnico $\mathrm{n}^{\circ} 1$, Belém, Instituto Evandro Chagas, $153 \mathrm{p}$.

Silva, D. F. \& S. D. Vasconcelos. 2005. Flebotomíneo em fragmentos de Mata Atlântica na Região Metropolitana do Recife, PE. Revista da Sociedade Brasileira de Medicina Tropical 38: 264-266.

Silva, F. S. \& J. M. M. Rebêlo. 1999. Euglossine bees (Hymenoptera: Apidae) of Buriticupu, Amazonia of Maranhão, Brazil. Acta Amazônica 29: 587-599.

Young D. G. \& M. A. Duncan. 1994. Guide to the identification and geographic distribution of Lutzomyia sand flies in Mexico, the West Indies; Central and South America (Diptera: Psychodidae). Memories of the American Entomology Institute 54: 1-881. 